\title{
Default options and training participation
}

\author{
Citation for published version (APA):
}

Borghans, L., \& Golsteyn, B. H. H. (2013). Default options and training participation. Maastricht University, Graduate School of Business and Economics. GSBE Research Memoranda No. 006 https://doi.org/10.26481/umagsb.2013006

Document status and date:

Published: 01/01/2013

DOI:

10.26481/umagsb.2013006

Document Version:

Publisher's PDF, also known as Version of record

\section{Please check the document version of this publication:}

- A submitted manuscript is the version of the article upon submission and before peer-review. There can be important differences between the submitted version and the official published version of record.

People interested in the research are advised to contact the author for the final version of the publication, or visit the DOI to the publisher's website.

- The final author version and the galley proof are versions of the publication after peer review.

- The final published version features the final layout of the paper including the volume, issue and page numbers.

Link to publication

\footnotetext{
General rights rights.

- You may freely distribute the URL identifying the publication in the public portal. please follow below link for the End User Agreement:

www.umlib.nl/taverne-license

Take down policy

If you believe that this document breaches copyright please contact us at:

repository@maastrichtuniversity.nl

providing details and we will investigate your claim.
}

Copyright and moral rights for the publications made accessible in the public portal are retained by the authors and/or other copyright owners and it is a condition of accessing publications that users recognise and abide by the legal requirements associated with these

- Users may download and print one copy of any publication from the public portal for the purpose of private study or research.

- You may not further distribute the material or use it for any profit-making activity or commercial gain

If the publication is distributed under the terms of Article $25 \mathrm{fa}$ of the Dutch Copyright Act, indicated by the "Taverne" license above, 


\section{Maastricht University}

Lex Borghans, Bart H.H. Golsteyn

Default options and training participation

RM/13/006

\section{GSBE}

Maastricht University School of Business and Economics

Graduate School of Business and Economics

P.O Box 616

NL-6200 MD Maastricht

The Netherlands 


\title{
Default options and training participation*
}

\author{
Lex Borghans ${ }^{\dagger} \quad$ Bart H.H. Golsteyn ${ }^{\dagger}$
}

February 17, 2013

\begin{abstract}
This paper analyzes whether defaults affect the choice for courses followed at work. In addition, we analyze whether the size of the default effect varies with employees' personality and skill-deficiencies. We perform an experiment in which workers are hypothetically offered three courses which they can accept or exchange for other courses. Randomizing the default package of courses, we identify the default effect. Default courses are chosen approximately three times more often than other courses. They are chosen more often if people have skill-deficiencies in these courses, suggesting that people consider the default to be an advice. Women choose default courses more often than men. Women with less self-confidence and men with lower cognitive skills choose the default courses more often.
\end{abstract}

Keywords: Human capital investment, Training, Default

JEL codes: J24, J31, I2

*The authors benefitted from valuable comments by Tim Barmby, Arnaud Dupuy, Rachel Griffith, Andries de Grip, Hans Heijke, David Huffman, Moshe Hazan, Huub Meijers, Markus Mobius, Erik Plug, Anders Stenberg, Bas ter Weel and seminar participants at Maastricht University, IZA, the 2005 NAKE day and the 2006 SOLE conference. Golsteyn thanks the Volkswagen Stiftung and Handelsbanken's forskningsstiftelser for financial support.

${ }^{\dagger}$ Department of Economics and the Research Centre for Education and the Labour Market (ROA), Maastricht University, lex.borghans@maastrichtuniversity.nl.

${ }^{\ddagger}$ Corresponding author. Department of Economics and the Research Centre for Education and the Labour Market (ROA), Maastricht University, and Swedish Institute for Social Research (SOFI), Stockholm University, b.golsteyn@maastrichtuniversity.nl, Postal address: P.O. Box 616, 6200 MD, Maastricht, the Netherlands. 


\section{Introduction}

A large literature in behavioral economics has shown that choices are determined to an important extent by the way in which the choice options are presented. Default options ${ }^{1}$ have been shown to strongly influence choices regarding organ donations (Johnson and Goldstein 2003, Abadie and Gay 2006), car insurances (Johnson, Hershey, Meszaros, and Kunreuther 1993), car purchases (Park, Yun, and MacInnis 2000), consent with e-mail marketing (Johnson, Bellman, and Lohnse 2002) and pensions with 401(k) saving (Carroll, Choi, Laibson, Madrian, and Metrick 2009). A likely explanation for this tendency to accept defaults is that people consider them to be an advice, which emphasizes the responsibility of those who set defaults.

It is conceivable that defaults also influence decisions regarding investments in human capital, yet no attempt has thus far been made to introduce the notion in this literature. This paper analyzes whether defaults affect the choice for courses followed at work. In addition, we analyze whether the size of the default effect varies with employees' personality and skill-deficiencies.

We use an experimental approach in which 4,312 young workers are asked to consider a hypothetical situation in which they are offered by their firm a package of three training courses. They can accept these courses or exchange them for courses from a menu of three alternatives. Randomizing the default offer allows us to identify the effect of defaults on choices for courses.

Our findings indicate that workers on average have a very strong propensity to choose the default courses. If a course is offered in the default set, the chance that a respondent chooses this course is approximately three times larger than if the course is not offered in the default set. The probability to accept the default is higher if the skill-deficiency of the respondent in the field of the training that is offered is higher. A default offer therefore seems to reinforce the individual perception of skill-needs. Women choose default courses more often than men. Relating choice behavior to personality, we find evidence that men with more cognitive skills and women with more self-confidence choose defaults less often. These findings contribute to the literature on the effect of personality traits on choice behavior (Mueser (1979), Bowles, Gintes, and Osborne (2001), Heckman, Stixrud, and

\footnotetext{
${ }^{1}$ Default options are pre-selected options which hold unless a different option is chosen.
} 
Urzua (2006), Borghans, Golsteyn, Heckman, and Meijers (2009)). ${ }^{2}$

Section 2 of this paper is concerned with the set-up of the experiment and a description of the data. Section 3 discusses the estimation method. Section 4 reports the results. Section 5 concludes.

\section{The experiment and the data}

The presentation of choice options has often been shown to influence choices. We investigate whether the presentation of choices also influences human capital decisions. Analyzing this question is not trivial. There are many factors which determine the decision to participate in training. Colquitt, LePine, and Noe (2000) show that psychological factors such as anxiety influence to a large extent whether people invest in human capital and Eraut (2000) shows that self-confidence is an important factor that stimulates course participation at work. The conditions under which people choose to follow education or training vary dramatically. Some people for instance have less time for training than others because of duties in the household and some employers may give more opportunities to follow training or education than others. Shields (1998) shows that participation in training differs substantially between workers and Field (2000) and Sargant and Aldridge (2002) have pointed out that course participation crucially depends on whether people face practical or financial impediments or stimuli to participate.

Because of this endogeneity, we will explore the the relationship between default options and training choices using an experiment. We choose to run an experiment which is hypothetical in nature. This enables us to run the experiment on a large group of individuals with varying backgrounds and occupations. In future research it would be interesting to test whether our results hold when applied to field experiments in which actual training courses are offered. One of the limitations of such a field experiment is that the results would apply to a small subsection of the population because the experiment would have to be run in a specific firm and with specific courses.

\footnotetext{
${ }^{2}$ See Borghans, Duckworth, Heckman, and ter Weel (2008) for an overview of this literature.
} 


\subsection{The sample and the experimental setup}

The participants in our experiment are graduates from professional college or university in the Netherlands. Each year, the Research Centre for Education and the Labour Market (ROA) gathers information among Dutch graduates to give representative overviews amongst others of the position of graduates on the labor market and their assessment of the quality of the education they followed. ${ }^{3}$ We were able to include our experiment in a follow-up survey. ${ }^{4}$ In total, 4,955 professional college and university graduates agreed to participate in the follow-up questionnaire. The experiment was held among the working respondents only: 4,312 graduates. Their average age is 26.8 years (standard deviation of 5.8 years), $62.7 \%$ is female, and one third of the sample has a university diploma while the others have a professional college diploma. ${ }^{5}$

In the experiment, we offer a fixed set of six courses to the respondents from which they have to choose three courses.

The choice of the set of six courses is related to a set of aspects included in the original school-leaver survey. Respondents are asked to indicate the level of their skills with respect to these aspects and they are asked which level of skills is required in their jobs with respect to the aspects. Table 1 gives the exact wording of the question and indicates the skills we will use to analyze our hypotheses: working well under pressure; applying ICT; communicating in foreign languages; drawing on other people's capabilities; working productively with other people; and working in accordance with a budget.

In our analysis, we will use the difference between the skills a person indicates to be required for the job and the skills he indicates to posses as a measure for his deficiency with respect to that skill. $55.9 \%$ of the respondents report skill-deficiencies regarding at least one of the selected skills.

- Table 1 -

The skills asked in the original survey are often too general in nature to offer as a

\footnotetext{
${ }^{3}$ In 2004, all 115,000 graduates from all levels in the Dutch educational system were approached 1.5 years after graduation. $45 \%$ of the graduates filled out the 2004 school-leaver survey.

${ }^{4}$ We asked respondents from the 2004 survey to fill out a questionnaire on internet called "Dealing with difficult choices." In the mail, we explained that the aim of the research is to increase understanding of how young people deal with difficult decisions, especially those related to educational choices. We explained that knowledge about these processes is of great societal and scientific importance since e.g. $20 \%$ of all graduates indicate that they regret their educational choice. To stimulate participation and deliberate answers, we offered the respondents upon completion of the questionnaire a profile about their personal style to deal with choices.

${ }^{5}$ Note that our sample consists of higher educated respondents only. It is therefore not representative of the full Dutch population.
} 
course to the graduates. In our follow-up survey, we therefore translate the general skills into more specific courses. Table 2 shows which course we use for each skill. Obviously, even more specific courses could be offered. We choose to leave it to the respondents to imagine which specific course they would take within the courses offered because of the potentially great diversity in the skill levels of the respondents and their specific needs.

- Table 2 -

The hypothetical offer of the courses reads as follows:

Suppose your work has a new settlement in which everyone can participate during working hours in the following courses, the expenses of which are fully covered by the employer: English, Computer skills, Stress Management. However, it is also possible to exchange one or more courses. The alternatives are Management skills, Team work, Efficient working. Do you choose the suggested set of courses or do you want to exchange?

Note that we phrase this question in a way that there are no financial or time-related restrictions to the employee. The question is also constructed such that the courses which are offered in the default package are the courses which the employer suggests to the employees. Thereby an advice or a statement about the most appropriate choice is generated.

To identify the effect of the default, we randomize the offered courses. We offer a first group of respondents courses in English, Stress management and Efficient working, with the alternative choices Computer use, Team working and Management ${ }^{6}$. A second group is offered English, Computer use and Stress management, with the alternatives Efficient working, Team working and Management. And a third group is offered Efficient working, Team working and Management, with the alternatives English, Computer use and Stress management.

The respondents first have to indicate whether they want to choose the offered package or whether they want to exchange courses. If they want to exchange, they have to indicate which courses to leave out and which to add.

\footnotetext{
${ }^{6}$ We translate the Dutch "Leiding geven" which implies supervising a team of people with "Management".
} 
We find that $29.7 \%$ of the respondents take the default package (i.e. all the courses offered by default), while the remaining respondents exchange at least one course for another course.

Choosing the default saves the respondent some time. One potential critique therefore is that respondents might choose the default to faster complete the survey. We checked whether the default is chosen more often by respondents who take less time to complete the survey. We find however the opposite: respondents who choose the default take on average more time to complete the survey. This might indicate that those who take a lot of time in each question are more hesitant when it comes to choosing. ${ }^{7} 8$

Table 3 shows that some courses are more popular than others. English, Computer courses and Team work are selected least often. This is in line with what we expected: respondents have had ample opportunities at school and in college to invest in these skills, so their deficiencies are lowest. The table shows furthermore that most people indicate that they need more skills related to Stress management, Management and Efficient working.

- Table 3 -

\subsection{Personality}

In our analysis, we will relate choice behavior to personality traits. We analyze relationships with the following traits: locus of control, anxiety, self-image, self-confidence, capacity to imagine the future, cognitive skills, and time preference. A comprehensive list of the questions measuring these traits is shown in table 4.

- Table 4 -

Locus of control refers to the extent to which individuals believe that they can control events that affect them. Individuals with an internal locus of control believe that events result primarily from their own behavior and actions. Those with an external locus of

\footnotetext{
${ }^{7}$ We find this relationship between choosing the default and responding slower in the survey for all 8 parts in the survey. The possibility that people who need more time to answer questions become impatient more easily further on in the survey and might therefore rush through the survey is therefore not supported by the evidence.

${ }^{8}$ One other potential issue is that respondents may have consulted other respondents when answering the survey. However, we believe that this is highly implausible. First, the survey was held two years after the respondents left college and it is unlikely that they take the time to discuss the survey with old friends from college. Second, the survey takes quite some time to complete and would take too long if people would extensively talk about these questions with their friends. Third, the incentive to consult other people is very low: the question is hypothetical, no monetary incentives are given, and there are no right or wrong answers.
} 
control believe that powerful others, fate, or chance primarily determine events. Those with an internal locus of control are more likely to assume that their efforts will be successful. They are more active in seeking information and knowledge concerning their situation. We expect them to be less affected by defaults than those with an external locus of control.

Colquitt, LePine, and Noe (2000) show that anxiety is important for choosing to participate in training. Anxiety indicates to which extent people are afraid of things they do not have experience with. We expect those with higher anxiety to follow suggestions by others more often and therefore to choose the default more often.

We expect those with a well developed self-image to know better what they want than those with a less developed self-image. Therefore, we expect that they will choose the default less often. People with more self-confidence may be less afraid to make choices and may follow suggestions by others less often. We expect them to choose the default less often.

When choosing between courses, it will be important to understand the significance of the investment for the accumulation of human capital. We expect therefore that having a high capacity to imagine the future will be related with investing less in the default. The capacity to imagine the future is measured by 9 statements about the image one has about the future (e.g. "I can imagine well what my next job will look like") and the experiences one has had in the past ("My life is now like I thought it would be 3 years ago").

We expect that people with more cognitive skills will better understand the significance of the investment and invest less in the default. Cognitive skills are measured by 8 questions taken from Frederick (2005). An example of these questions is:

"Together, a ball and a cap cost 1.10 Euros. The ball costs 1.00 Euros more than the cap. How much does the cap cost?"

Frederick (2005) shows that scores on this Cognitive Reflection Test are correlated with SAT-scores and scores on several other IQ tests and with the ability to make choices. We find significant correlations between the average number of correctly answered questions and high school grades for nearly all subjects taught in high school and with the average 
college grade. This indicates that the measure plausibly reflects some general type of cognitive skills.

People with high time preference (i.e. who value the future less) may be less interested in investing time to understand in which courses they could invest best and therefore choose the default option more often. Time preference is measured by the question:

"Suppose you win a 10-day holiday trip worth 2000 euros to an interesting destination. To spread participation, you are asked if you can delay your trip with three years in exchange for a longer vacation. How many days should you be offered in addition to accept the offer in 3 years?"

We find that $97.6 \%$ of the respondents answer that they would want to be offered between 0 and 30 days in addition to accept the offer. On average people answer 11.6 days (standard deviation 9.0). This corresponds to a time preference rate of $27.0 \% .^{9}$ Compared with an interest rate at a bank this average time preference is therefore very high. In the literature (Frederick, Loewenstein, and O'Donogue 2002) it is known that the measure of time preference is strongly influenced by anchoring effects but that some people consistently score higher or lower on these measures. We validate the measure for time preference with a measure which is used often in psychology (Rachlin, Raineri, and Cross 1991). This measure uses trade-offs between amounts of money now and amounts of future money to elicit time preference and is significantly correlated with our time preference measure (correlation: 0.156, t-value: 6.741).

\section{Method}

We analyze within-person effects of having a course in the default package on the choice for this course. Let $p_{i c}$ be the probability that individual $i$ chooses course $c$ and $X_{i c}$ be a vector of course characteristics for the individual. We postulate the conditional (fixed-effect) logit regression

$$
\ln \frac{p_{i c}}{1-p_{i c}}=\alpha X_{i c}+\beta Z_{c}+v_{i}+\varepsilon_{i c}, i=1, \ldots, N, c=2, \ldots, 6
$$

\footnotetext{
${ }^{9}$ In the tables, we divide this time preference by 100.
} 
where $Z_{c}$ represents a vector of dummies for the courses (excluding one course as the reference category) with which we control for average differences in preferences between courses, $v_{i}$ represents the individual fixed effect and $\varepsilon_{i c}$ the error term. The coefficient $\alpha$ measures the extent to which course characteristics affect the choice for courses.

In our basic specification, $X$ includes a dummy variable indicating whether for the individual the course is offered in the default package. In a more elaborate specification of the model, $X$ additionally includes the skill-deficiency of an individual in the field related to the course and the interaction between the default and the skill-deficiency variable. In another specification of the model, we include interactions of personality traits with the default variable. In this specification, $X_{i c}$ is replaced by: $X_{i c}=\beta_{0} X_{i c}+\sum_{1}^{k} \beta_{k} X_{i c} \Psi_{i k}$ in which $\Psi$ is a vector of $k$ personality traits.

\section{Results}

Table 5 shows the main results of our analysis: courses which are in the default package are chosen approximately three times more often than courses which are not in the default package. Separately running the regression for men and women, we find that the effect of the default is stronger for women (default courses are chosen 3.3 times more often) than for men (default courses are chosen 2.8 times more often).

- Table $5-$

Table 6 includes the skill-deficiency variable in the regression. The results show that people choose courses in which they are skill-deficient more often than courses in which they are less skill-deficient. The effect of the default remains similar when we include the skill-deficiency variable. This shows that the allocation of courses in the default package is not related to the skill-deficiency. As we discussed earlier, the random allocation of courses in the default package is an important condition for identifying the effect of the default.

In the last column of the table we include an interaction of the skill-deficiency with the default in the regression. We find that workers more often choose courses which reduce their skill-deficiency if these courses are in the default package. 
- Table $6-$

Table 7 shows the interactions of gender and personality traits with the default variable. We find that the earlier indicated difference between men and women is statistically significant. Workers with more cognitive skills, less anxiety and more self-confidence choose the default less often. Separating these results for men and women, we find that men with lower cognitive skills or more anxiety and women with lower self-confidence or a less developed self-image choose the default more often.

- Table 7 -

\section{Conclusions}

This paper shows that the choice for courses followed at work depends on defaults set by employers. Default courses are chosen approximately three times more often than courses which are not in the default package. Women choose default courses more often than men. Women with less self-confidence and men with lower cognitive skills choose the default more often. Default courses are chosen more often if people are skill-deficient in these courses.

Our estimates suggest that managers and training specialists have an important role in the development of workers' human capital. Setting courses as defaults is a form of libertarian paternalism which has the advantages that it does not prohibit workers to choose the training they consider to be best, while at the same time it may help employees who are not choosing actively to pick courses that effectively develop their human capital. One obvious question here is to which extent the employer's interest is in line with the employee's interest. Employers may for instance be more likely to set defaults which develop employees' firm specific human capital instead of their general human capital. Choosing the default may in this case not advance an employee's selfinterest most effectively. The extent to which this occurs is an interesting area for future research.

Our analysis serves as a starting point for gathering evidence on the choices people make regarding education and training. Our paper has some shortcomings which we are unable to address with the current experiment. One shortcoming is that we do not 
explicitly investigate the role of the firms where the respondents work. Choosing the default may be related to experiences a respondent has had at the firm in the past. Another shortcoming is that in our experiment no incentives are given to choose the best courses. It is important to show whether the default effects remain when incentives are given. Field experiments in which actual courses are offered could be an interesting setting to study if the default effect remains in a real-life setting. One of the advantages of our approach is that we can study the effects in a broad spectrum of the population while field experiments necessarily focus on a specific subsample of the population.

\section{References}

Abadie, A., And S. Gay (2006): "The Impact of Presumed Consent Legislation on Cadaveric Organ Donation: A Cross Country Study," Journal of Health Economics, 25(4), 599-620.

Borghans, L., A. L. Duckworth, J. J. Heckman, and B. ter Weel (2008): "The Economics and Psychology of Personality Traits," Journal of Human Resources, 43(4), $972-1059$.

Borghans, L., B. Golsteyn, J. J. Heckman, and H. MeiJers (2009): “Gender Differences in Risk Aversion and Ambiguity Aversion," Journal of the European Economic Association, 7(2-3), 649-658.

Bowles, S., H. Gintes, And M. Osborne (2001): "The Determinants of Earnings: A Behavioral Approach," Journal of Economic Literature, 39(4), 1137-1176.

Carroll, G., J. Choi, D. Laibson, B. Madrian, and A. Metrick (2009): "Optimal Defaults and Active Decisions," Quarterly Journal of Economics, 124(4), 16391674

Colquitt, J., J. LePine, And R. Noe (2000): "Towards an Integrative Theory of Training Motivation: A Meta-Analytic Path Analysis of 20 Years of Research," Journal of Applied Psychology, 85(5), 678-707.

Eraut, M. (2000): "Non-Formal Learning and Tacit Knowledge in Professional Work," British Journal of Educational Psychology, 70(1), 113-136. 
FiELD, J. (2000): Lifelong Learning and the New Educational Order. Trentham Books, Stoke on Trent.

Frederick, S. (2005): "Cognitive Reflection and Decision Making," Journal of Economic Perspectives, 19(4), 25-42.

Frederick, S., G. Loewenstein, and T. O’Donogue (2002): "Time Discounting and Time Preference: A Critical Review," Journal of Economic Literature, XL, 351401.

Heckman, J., J. Stixrud, and S. Urzua (2006): "The Effects of Cognitive and Noncognitive Abilities on Labor Market Outcomes and Social Behavior," Journal of Labor Economics, 24(3), 411-482.

Johnson, E., S. Bellman, and G. Lohnse (2002): "Defaults, Framing and Privacy: Why Opting In-Opting Out," Marketing Letters, 13(1), 5-15.

Johnson, E., And D. Goldstein (2003): "Do Defaults Save Lifes?," Science, 302, $1338-1339$.

Johnson, E., J. Hershey, J. Meszaros, and H. Kunreuther (1993): "Framing, Probability Distortions, and Insurance Decisions," Journal of Risk and Uncertainty, $7(1), 35-53$.

Mueser, P. R. (1979): "The Effects of Noncognitive Traits," in Who Gets Ahead? The Determinants of Economic Success in America, ed. by C. Jencks, pp. 122-158. New York: Basic Books.

Park, C., S. Yun, And D. MacInnis (2000): "Choosing What I want Versus Rejecting What I Do Not Want: An Application of Decision Framing to Product Option Choice Decisions," Journal of Marketing Research, 37(2), 187-202.

Rachlin, H., A. Raineri, And D. Cross (1991): "Subjective Probability and Delay," Journal of the Experimental Analysis of Behavior, 55, 233-244.

Sargant, N., and F. Aldridge (2002): Adult Learning and Social Division: A Persistent Pattern, Vol. 1. NIACE, Leicester. 
ShiElds, M. (1998): "Changes in the Determinants of Employer-Funded Training for Full-Time Employees in Britain," Oxford Bulletin of Economics and Statistics, 60, 189214. 
Table 1: Required and own level of aspects in job

\begin{tabular}{|c|c|c|}
\hline $\begin{array}{l}\text { Below are aspects that could be of importance in your job. } \\
\text { Rate for each of these aspects: }\end{array}$ & $\begin{array}{l}\text { The required level } \\
\quad \text { in your job } \\
\text { Average }<->\text { Excellent }\end{array}$ & $\begin{array}{c}\text { Your own level } \\
\text { Average }<->\text { Excellent }\end{array}$ \\
\hline $\begin{array}{l}\text { Working well under pressure } \\
\text { Applying ICT } \\
\text { Communicating in foreign languages } \\
\text { Drawing on other people's capabilities } \\
\text { Working productively with other people } \\
\text { Working in accordance with budget, planning or guidelines }\end{array}$ & $\begin{array}{lllll}1 & 2 & 3 & 4 & 5 \\
1 & 2 & 3 & 4 & 5 \\
1 & 2 & 3 & 4 & 5 \\
1 & 2 & 3 & 4 & 5 \\
1 & 2 & 3 & 4 & 5 \\
1 & 2 & 3 & 4 & 5\end{array}$ & $\begin{array}{lllll}1 & 2 & 3 & 4 & 5 \\
1 & 2 & 3 & 4 & 5 \\
1 & 2 & 3 & 4 & 5 \\
1 & 2 & 3 & 4 & 5 \\
1 & 2 & 3 & 4 & 5 \\
1 & 2 & 3 & 4 & 5\end{array}$ \\
\hline
\end{tabular}

Source: Research Centre for Education and the Labour Market 2004 Graduate Survey.

Table 2: Courses offered related to the skills

\begin{tabular}{l|r}
\hline \hline Skill $^{a}$ & Course $^{b}$ \\
\hline Working well under pressure & Stress Management \\
Applying ICT & Computer \\
Communicating in foreign languages & English \\
Draw on other people's capabilities & Management \\
Working productively with other people & Team Work \\
Working in accordance with budget, planning or directions & Efficient working \\
\hline \hline
\end{tabular}

Source: Research Centre for Education and the Labour Market 2004 Graduate Survey and 2005 supplement.

${ }^{a}$ Question asked in the 2004 survey to analyze the required and own level of skills.

${ }^{b}$ Translation of the skill into the specific course offered in the 2005 supplement.

Table 3: The choice of courses and the percentage of respondents skilldeficient in a course

\begin{tabular}{l|cc}
\hline \hline & Chooses course (\%) & Deficiency $^{a}(\%)$ \\
\hline English & 39.1 & \\
Efficient work & 71.5 & 10.7 \\
Team work & 46.8 & 21.3 \\
Management & 70.8 & 12.4 \\
Computer & 18.3 & 22.4 \\
Stress Management & 53.4 & 11.7 \\
& & 22.8 \\
\hline \hline
\end{tabular}

Source: Research Centre for Education and the Labour Market 2004 Graduate Survey and 2005 supplement.

${ }^{a}$ Percentage of the respondents who are skill-deficient. A skill-deficiency is defined as the difference between the self-assessed required level of skills on the job and the self-assessed own level of skills. 


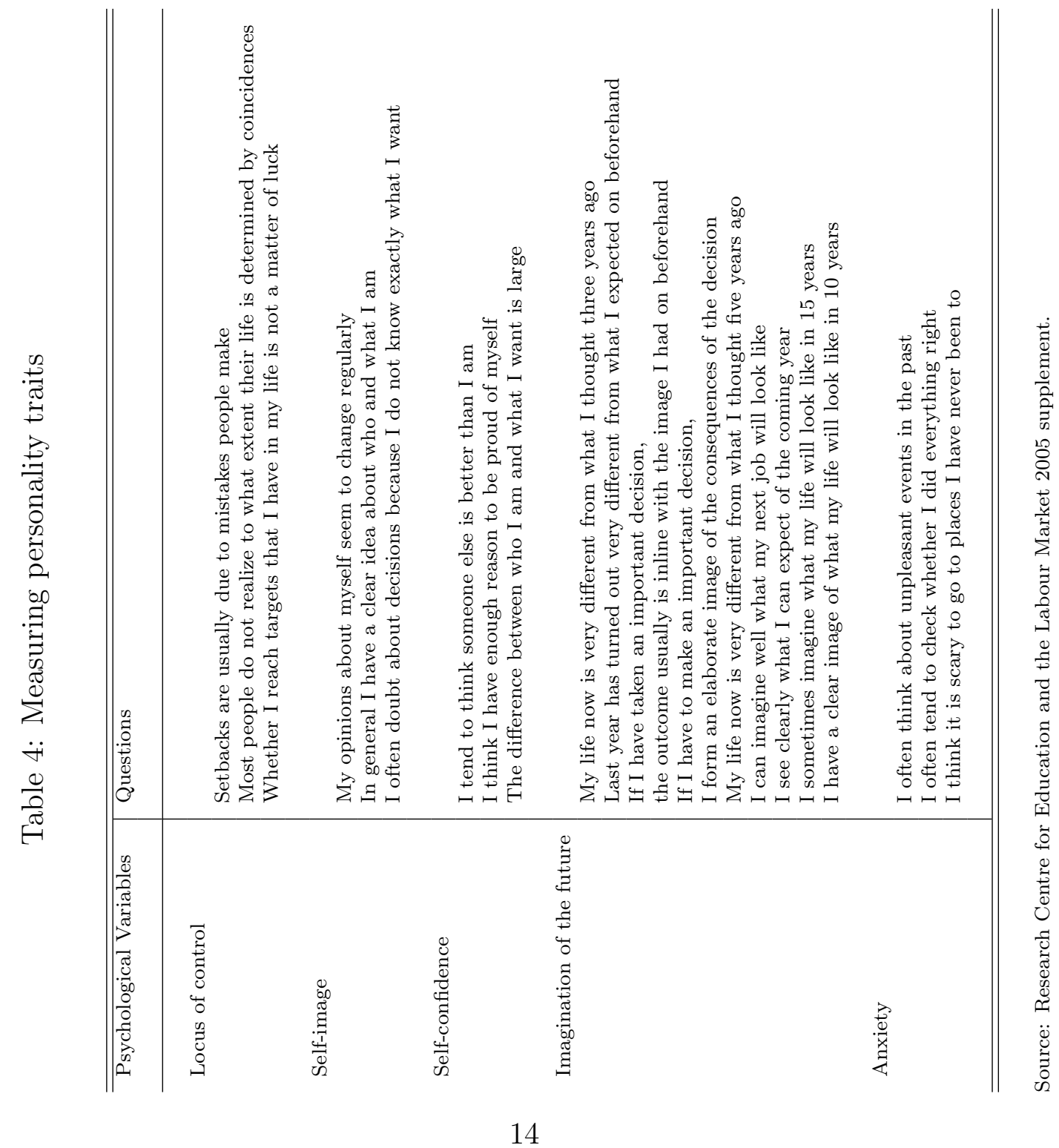




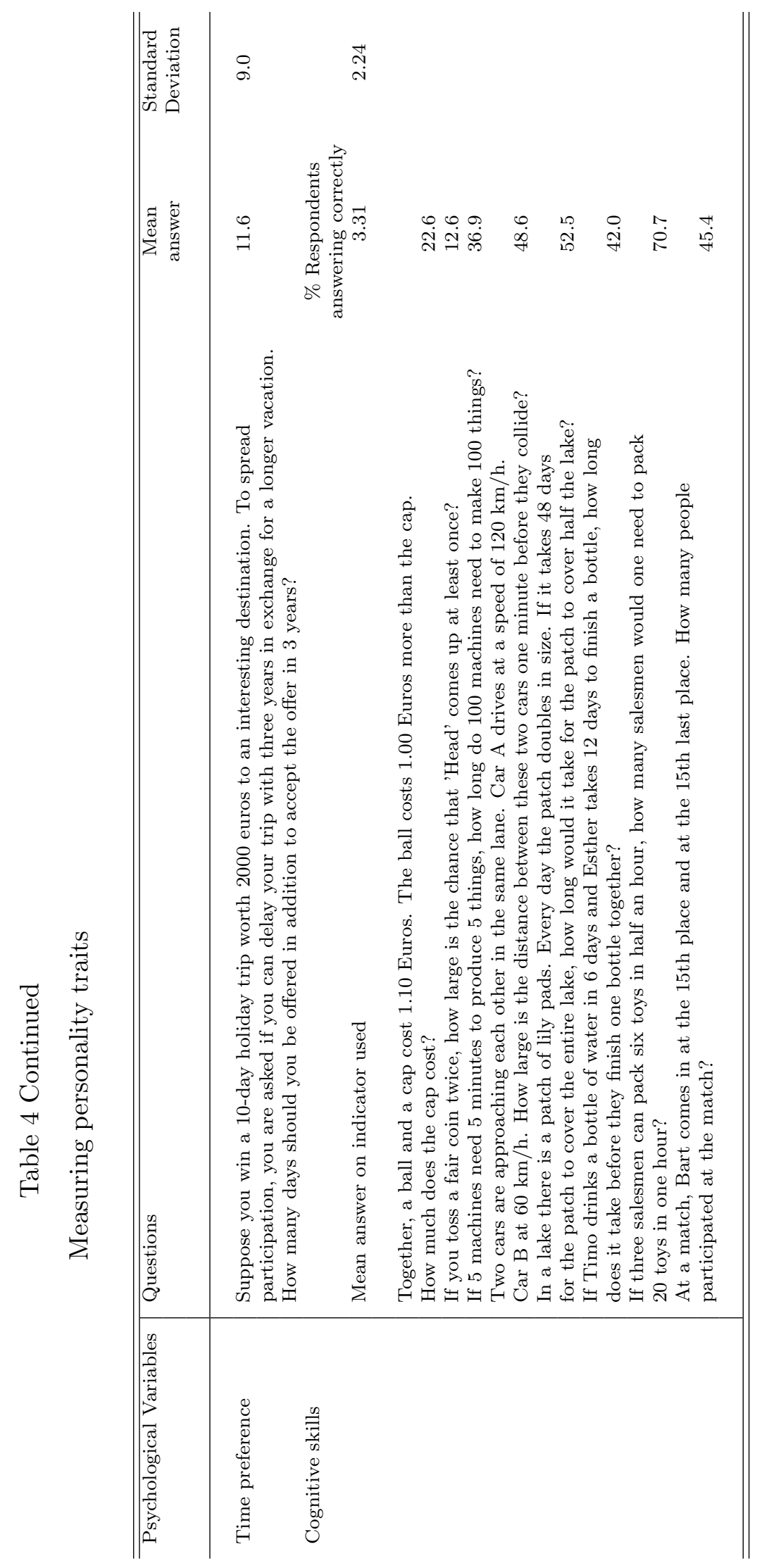


Table 5: Default and the choice for courses

\begin{tabular}{lccc}
\hline & $(1)$ & $(2)$ & $(3)$ \\
& All & Women & Men \\
& & & \\
\hline Default & $3.072^{* * *}$ & $3.263^{* * *}$ & $2.759^{* * *}$ \\
& $(0.089)$ & $(0.120)$ & $(0.132)$ \\
Dummies per course & Included & Included & Included \\
$\mathrm{N}$ & 4296 & 2695 & 1601 \\
\hline \multicolumn{4}{c}{ Each column shows the result of a conditional logit model. } \\
The coefficients are odds ratios. Standard errors in parentheses. \\
$* * *$ p $<0.01,{ }^{* *} \mathrm{p}<0.05,{ }^{*}$ p $<0.1$
\end{tabular}

Source: Research Centre for Education and the Labour Market 2005 graduate survey supplement.

Table 6: Default, skill-deficiency and the choice for courses

\begin{tabular}{lccc}
\hline & $(1)$ & $(2)$ & $(3)$ \\
& All & All & All \\
& & & \\
\hline Default & $3.072^{* * *}$ & $3.194^{* * *}$ & $3.303^{* * *}$ \\
& $(0.089)$ & $(0.099)$ & $(0.106)$ \\
Skill-deficiency & & $1.139^{* * *}$ & $1.053^{* *}$ \\
& & $(0.020)$ & $(0.025)$ \\
Default*Skill-deficiency & & & $1.139^{* * *}$ \\
& & & $(0.033)$ \\
Dummies per course & Included & Included & Included \\
$\mathrm{N}$ & 4296 & 3850 & 3850 \\
\hline \multicolumn{2}{c}{ Each column shows the result of a conditional logit model. }
\end{tabular}

Each column shows the result of a conditional logit model.

The coefficients are odds ratios. Standard errors in parentheses. $* * * \mathrm{p}<0.01, * * \mathrm{p}<0.05,{ }^{*} \mathrm{p}<0.1$

Source: Research Centre for Education and the Labour Market 2005 graduate survey supplement. 
Table 7: Default, personality and the choice for courses

\begin{tabular}{|c|c|c|c|c|}
\hline & $\begin{array}{l}\text { (1) } \\
\text { All }\end{array}$ & $\begin{array}{l}(2) \\
\text { All }\end{array}$ & $\begin{array}{c}(3) \\
\text { Women }\end{array}$ & $\begin{array}{l}\text { (4) } \\
\text { Men }\end{array}$ \\
\hline Default & $\begin{array}{c}3.072^{* * *} \\
(0.089)\end{array}$ & $\begin{array}{c}3.447^{* * *} \\
(0.122)\end{array}$ & $\begin{array}{c}3.318^{* * *} \\
(0.125)\end{array}$ & $\begin{array}{c}3.037^{* * *} \\
(0.170)\end{array}$ \\
\hline Default*Male & & $\begin{array}{c}0.829^{* * *} \\
(0.045)\end{array}$ & & \\
\hline Default*Cognitive skills & & $\begin{array}{c}0.935 * * \\
(0.025)\end{array}$ & $\begin{array}{c}0.954 \\
(0.032)\end{array}$ & $\begin{array}{c}0.907^{* *} \\
(0.039)\end{array}$ \\
\hline Default*Locus of control & & $\begin{array}{c}0.974 \\
(0.025)\end{array}$ & $\begin{array}{c}0.961 \\
(0.032)\end{array}$ & $\begin{array}{c}0.985 \\
(0.040)\end{array}$ \\
\hline Default*Anxiety & & $\begin{array}{l}1.049^{*} \\
(0.031)\end{array}$ & $\begin{array}{l}1.040 \\
(0.037)\end{array}$ & $\begin{array}{l}1.088^{*} \\
(0.054)\end{array}$ \\
\hline Default*Self-Image & & $\begin{array}{c}0.948 \\
(0.033)\end{array}$ & $\begin{array}{l}0.926^{*} \\
(0.040)\end{array}$ & $\begin{array}{c}0.988 \\
(0.058)\end{array}$ \\
\hline Default*Self-confidence & & $\begin{array}{c}0.871^{* * *} * \\
(0.030)\end{array}$ & $\begin{array}{c}0.839 * * * \\
(0.037)\end{array}$ & $\begin{array}{c}0.937 \\
(0.055)\end{array}$ \\
\hline Default*Time preference & & $\begin{array}{c}0.993 \\
(0.025)\end{array}$ & $\begin{array}{c}1.021 \\
(0.032)\end{array}$ & $\begin{array}{c}0.937 \\
(0.040)\end{array}$ \\
\hline Default*Imagination & & $\begin{array}{c}0.964 \\
(0.026)\end{array}$ & $\begin{array}{l}0.979 \\
(0.033)\end{array}$ & $\begin{array}{c}0.943 \\
(0.042)\end{array}$ \\
\hline $\begin{array}{l}\text { Dummies per course } \\
\mathrm{N}\end{array}$ & $\begin{array}{l}\text { Included } \\
4296\end{array}$ & $\begin{array}{l}\text { Included } \\
4296\end{array}$ & $\begin{array}{l}\text { Included } \\
2695\end{array}$ & $\begin{array}{c}\text { Included } \\
1601\end{array}$ \\
\hline
\end{tabular}

Source: Research Centre for Education and the Labour Market 2005 graduate survey supplement. 